\title{
紙パルプ製造工程における計装技術の歩みと今後の展望
}

横河電機侏紙パ技術部 山本 重彦，市川 真昭

\section{Review and future prospect of instrumentation techniques in pulp and paper processes}

\author{
Shigehiko Yamamoto and Masaaki Ichikawa \\ Yokogawa Electric Corporation
}

\begin{abstract}
Recently pulp and paper plants became more sophisticated, and the role of instrumentation techniques became essential for their operation. This paper reviews the history of the development of instrumentation techniques in pulp and paper processes. The paper stresses the importance of maintenance techniques in a total production system in future. The paper also discusses emerging techniques such as neural network and process simulation to reduce the operators work load.
\end{abstract}

\section{1.はじめに}

紙パルプ産業の歴史は古く，そのルーツは紀元前に さかのぼるとされている。日本においても中国より伝 えられたとされる製紙技術は，改良に改良が重ねられ て優美で強靶な和紙として現在でも立派に生き残って いる。

一力, 印刷機が発明された 15 世紀頃から紙の需要は 大幅に伸び，製紙技術は機械化されて大量生産される ようになった。

製紙技術は海外で発達し, 日本へは 1872 年 (明治 5 年）に最初の抄紙機が導入された。その後の製紙技 術の発展は“紙は文化のバロメーター”と評される通 り社会, 経済, 文化の発展とともに歩んできている。

このような製紙技術を支えているものに計装技術が ある。人間の五感に頼っていた手抄きの時代に比べ, 設備が大型化, 高速化している現在では計測, 制御技 術はより重要になっている。

そこで紙パルプ製造工程における計装技術のトレン ドを分析し，その課題を明らかにするとともに将来の 展望を予測してみたい。

\section{2. 紙パルプ計装技術の歩み}

プラント運転における中枢神経として発達してきた 計装技術も社会のニーズと密接に関係している。表 1 は計装技術のトレンドを社会, 経済および紙パルプ産 業の変遷に合せて記したものである。

我が国のプロセス計装の歴史は手動運転の時代, 自
動計測制御の幕開けとなった大型計器及び小型計器の 時代，高度な制御の実現に向けたプロセスコンピュー 夕一の導入期, そして近年目覚ましい発展を遂げてい る分散型総合計装システムの時代に分けることができ る。

\section{1 手動運転の時代}

日本における自動計測，制御技術が開発されたのは 戦後の昭和 20 年代であり，それ以前は全て人間の五感 による手動運転の時代であった。手動連転の時代には, オペレータは現場操作が基本であり, 現場設置の指示 計, 或いはチェスト等のプロセスそのものを見ながら バルブを操作していたのである。手動運転で活躍した のは温度，压打な゙の現場指小計とマノメータであっ た。

\section{2 自動計測, 制御の時代}

1) 大型計器の時代

戦後, 昭和 20 年代に入って伀送器による信号の統一 とともに, 大型の空気式調節計が開発され自動制御の 時代に入った。オリジナル技術は海外から導入され， 技術提携という形で国産化が一斉に始まった。調節部 はノズル・フラッパーとベローズを組合せた空気压式 であり，これに真空管とサーボモー夕を組合せた大型 の自動平衝式指示記録部を付加したものが主流を占め ていな。

代表的なものにラウンドチャート記録タイプの大型 記録調節計があり，これらをパネルマウントしな現場 制御盤が多く採用された。当時は調節計を採用する ループは主要ループに限られており, 手動操作が平行 
表 1 計装技術のトレンド

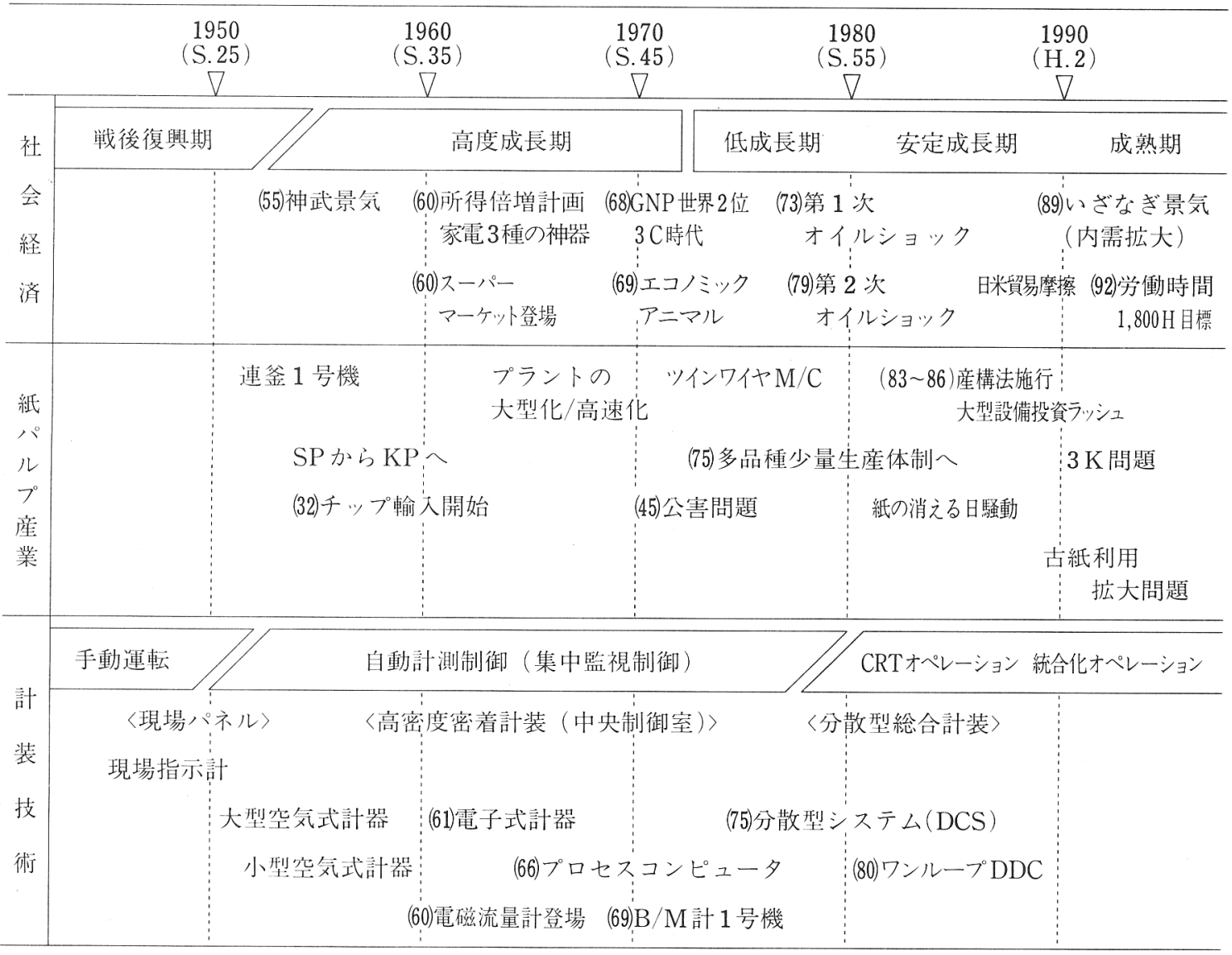

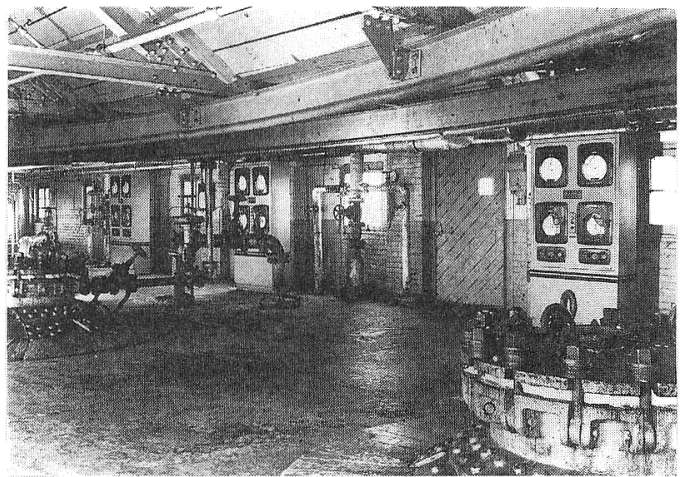

写真 1 バッチ木鉒の計装例

して行われていた。

写真 1 にバッチダイジェスタの計装例を示す。

2) 小型計器の時代 (パネル計装時代)

昭和 30 年代に入って高度成長期を迎える頃になる

と, プラントの大型化, 高速化が進み大量生産時代の
幕開けとなった。

これに伴い計装ループの数は飛躍的に増加してきた ため, 従来の大型調節計ではパネル占有面積が問題に なること，またループ数の急增により手動運転が困難 となり，市場ニーズとして小型化が必須となったので ある。

紙パルプ産業においては腐触性ガスの発生, パルプ 液を浴びる被害等の計装機器の設置環境が悪いことが 大きな特徴であるが，このような悪環境から計装機器 を守るのに自分自身でエアパージしてくれる空気式計 装は紙パルププロセスの計装機器として最適であった といえる。

昭和 30 年代終りにはトランジス夕回路を用いた小 型電子式計器が開発され，他産業には積極的に採用さ れていったが紙パルプ産業への導入は遅れた。紙パル プ産業において電子式計器が積極的に採用されるよう になったのは昭和 40 年代後半からである。これは電子 式計器の耐環境性の問題が解決したことが大きな要因 
である。そして空気式計装の欠点である信号の長距離 伝送に達れが発生する問題を電子式計装が見事に解決 したことと，コンピュータとの接続の優位性によると ころが大である。

しかしながらダイジェス夕等の雾囲気の悪いプロセ スにはやはり空気式計装が主流を占めていたのもこの 時代である。

\section{3 プロセスコンピュータの導入}

プロセスコンピュータが産業界で一般的に使われ始 めたのは昭和 40 年代である。最初はプロセスの監視や データロガーとしての要素が強く, 制御システムへの 適用は各種アプリケーションが開発されてからである。 ここで特筆すべきことは，半導体技術の進歩とともに 低価格のコンピュー夕が出現してきており，定型的な アルゴリズムを共通ルーチンとして一般化し，いわゆ るDDC (Direct Digital Control) システムが完成し たことである。

これが計算機制御の幕開けとなったのである。この 技術は現在の DCS に引き継がれ計算機を意識しない 一般化されたシステムへと発展する基礎となっている。

\subsection{CRT オペレーション}

第 1 次及び第 2 次オイルショックによる経済の停滞 により大量生産, 大量消費の時代は終った。社会生活 が多様化し，消費者ニーズが個性化してきた結果，生 産プロセスは多品種少量生産体制を余儀なくされてき たのである。

そこで計装技術へのニーズは品質制御システム，コ ストセービングシステムの開発が最大のテーマとなっ てきた。1975 (S 50) 年 CRT オペレーションを基本と した分散型総合計装制御システムが登場し，本格的な ディジタル計装の幕開けとなった。

紙パルププロセスの制御技術上の特徴はむだ時間が 長いことであり，そのことが制御方式そのものを難し くしている。

このようなむだ時間の長いプロセスはフィードバッ ク制御で対応するには難しく, フィードフォワード制 御 (予測制御) が必要になってくる。このような問題 に対してはディジタル方式である分散型計装が最適で ある。

一方，オペレーション方式は従来のパネルオペレー ションからCRTオペレーションへと大变勒あり, 現在でもその得失は論じられているが，いずれにして もその特徵を生かして次世代の計装へと発展していく ものと思われる。

\section{5 紙パルプ産業にインパクトを与えた計装技術} 紙パルプ産業の発展に寄与した計装技術の中で最も
インパクトを与えたものは, 電磁流星㖕と $\mathrm{B} / \mathrm{M}$ 計で あるといえるのではないだろうか。

\section{1) 電磁流量計}

電磁流量計が登場したのは 1960 年頃である。それま で紙パルプ産業においてオンラインでの正確なパルプ の物量測定は不可能であった。

紙の生産量とチップやパルプの使用量が大幅に食い 違い,生産活動の大きな支障となっていた。時にはチッ プヤードの一山が消えてしまったなどといわれていた。 このような状洸の中で登場した電磁流星計は非ニュー トニアン流体であるパルプ液を，オリフィスのような 絞りを入れることなく測定できることは画期的であっ た。しかしながら導入当初から思惑通りに測定できた かというと，そうではなく耐ノイズ性が弱く，アース の問題或いは工事上の溶接ノイズ等で泣かされたのは 記憶に新しい。現在ではセラミック笔磁なども開発さ れ, 今まで問題となっていた耐温度, 耐磨耗性, 耐付 着性が解決されてアプリケーションが非常に拡大して いる。

\section{2) $\mathrm{B} / \mathrm{M}$ 計}

現在， $\mathrm{B} / \mathrm{M}$ 計は抄紙機の一構成要素として必須と なっているが，その成長過程はユーザとメーカの努力 以外の何ものでもない。いいかえればユーザとメーカ の協力により開発されたシステムは他にも数多くある が，紙パルプ産業への最大のインパクトをケえたもの は $\mathrm{B} / \mathrm{M}$ 計である。

$\mathrm{B} / \mathrm{M}$ 計の国産 1 号機は 1969 年に登場したが，セン サは $\mathrm{B}$ 計と $\mathrm{M}$ 計のみであり，アナログ方式によるも のであった。

$\mathrm{B} / \mathrm{M}$ 計の素晴らしさは抄紙機のエンドポイントセ ンサ\&コントロールシステムであり, 㖕装技術として は測定と制御とデー夕処理（情報処理）の技術が融合 した最先端を行くものである。このようなシステムは 他産業にも例を見ることがなく，紙パルプ産業が誇れ るシステムの一つである。

しかしながら，現在のレベルまで到達するまでには ユーザ，メ一カ共に並大抵の苦労ではなかった。例え ば測定デー夕のオンライン検定における吸放湿の問題, 或いは叮択との相関等, 神様オペレータの “感”の世 界との整合性をとる作業は大変な苦労であった。神様 オペレータの “感”は素晴らしいものがあり，しばし ば助けられた事もある。また制御システム開発におい ては, 例えば自動抄替え制御システム開発の際，4直 のオペレータの作業を分析をしたところ作業目的と作 業内容が直によってまちまちであり, 開発担当は面食 らったというエピソードもある。そこで徽底的にオぺ 
レータとディスカッションし，現在の抄替え制御シス テムが珄まれたのである。いずれにしても $\mathrm{B} / \mathrm{M}$ 計は 今後益々品級化, 複雑化する抄紙機のエンドポイント コントロールシステムとしてその機能をグレードアッ ブしていくであろう。

\section{3. 計装技術の現状と将来展望}

\section{1 計装技術の現状と課題}

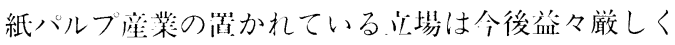
なることが想されて抢り，|目際競争力，労働環境 (3

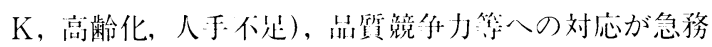
になっている。こ机らの䦌題!吕をクリヤするために計 装技術の伯から見て，現状と課題を考察寸る。

\section{測定技術}

紙パルプブロセス特们のセンサーは近年，海外から の供給でその種類は人幅に增えたが問題はまだまだコ ストが高く，㸚軽に等人できないものが多い。国産す るにはメーカとしてけ埸規模を考えた場合, ROI (Return of Investment) に耐えられないのが最大の ネックとなっている。今後の課題の一つであろう。

\section{制御技術}

制御技術そのものはアナログからディジタル計装に なったところで連鉒，眖，抄紙機といったユニットプ ロセスに対しての最適化制御といったものはアプロー チが比較的容易になった。現在でもファジー, AI，モ デル予測制御といったアドバンスドコントロールが盛 んに適用されつつある。したがつて, 従来の PID を主 体としたプロセス制御からユニットプロセスを対象と した品質制御の時代へ人つたといえる。

\section{操業技術}

近年, CRTオベレーションが導入され，オペレータ の役割が非常に重装になってきた。分散型計装システ ム (DCS) では過去のデー夕を駆使して垷在の運転状 沇を把握し，さらに将米を当測することが少しずつ可 能になってきている。そこで DCS 有效に使いプラ ントの问動化，收適化在成功させることはオペレー ションエンジニアの重览な仩事となってきた。

以上，計装技術の現状を踏ま之今後の課題をマクロ 的にとらえると次のようになる。

(1) 部分最適化から全体最適化一

従来，斗打，流早，温度といった単一のプロセス制 御が亡流であったが今後は連釜, 明といったプラント のユニット単位の早適化を目指し, 最終的にはパルプ プラント全体，或いは「莂全体の最適化を目指す。

(2) 統 合 化

工場全体のオペレーションの統合化により最少人数
で最高の効率で生産活動することを目指す。

これらを实現させる計装技術の今後のアプローチと して

(1) プロダクションセンタ構想

(2) 無人化システム

(3) 設備管理 について考察する。

\section{2 プロダクションセンタ構想}

次世代の生産システムとして要求されるものをまと めてみると次のようになる。

$$
\text { 二ーズ 対 策 }
$$

(1) 生産技術の高度化 〕プロセス生産システム の高度化

信頼性の向.上:

(2) 企業競争力の強化 $\Rightarrow$ コストダウン. 差別化 技術

（3)社会環境の变化への ら自動化による無人化 対応魅力ある紙パルプて埸

つまり『連転の自動化．統合化による無人化』 『コンピュータ統合化による最適生産』 ということになる。

従来からの生糜システムは図 1 に示すようにピラ ミッド型生産システムになっている。当然のことなが ら組織もこの生産システムと同様にピラミッド型に なっている。このピラミッド型の生産システムに対し 次世代の生産システムはフラット型の総合生産システ ムになると思われる。

そのシステムの中核をなすのがプロダクションセン 夕である。基本的な概念は『自動化・統合化システム を中心とする運転部門と生産管理, 設備管理, 帘企管 理，等の連転支援部門を一堂に配置し，全機能が生産 に集中することにより，高度で効率の高い生産活動の 体制を確立する』ことである。プロダクションセンタ の各機能のブレイクダウンを図 2 に示す。

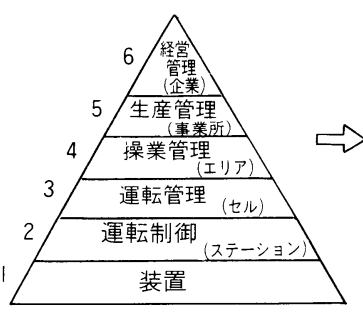

〈従来〉

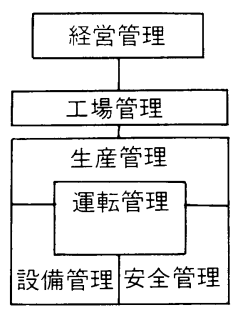

〈プロダクションセンター〉
図 1 ピラミッド型生産システムから総合生産シ ステム 


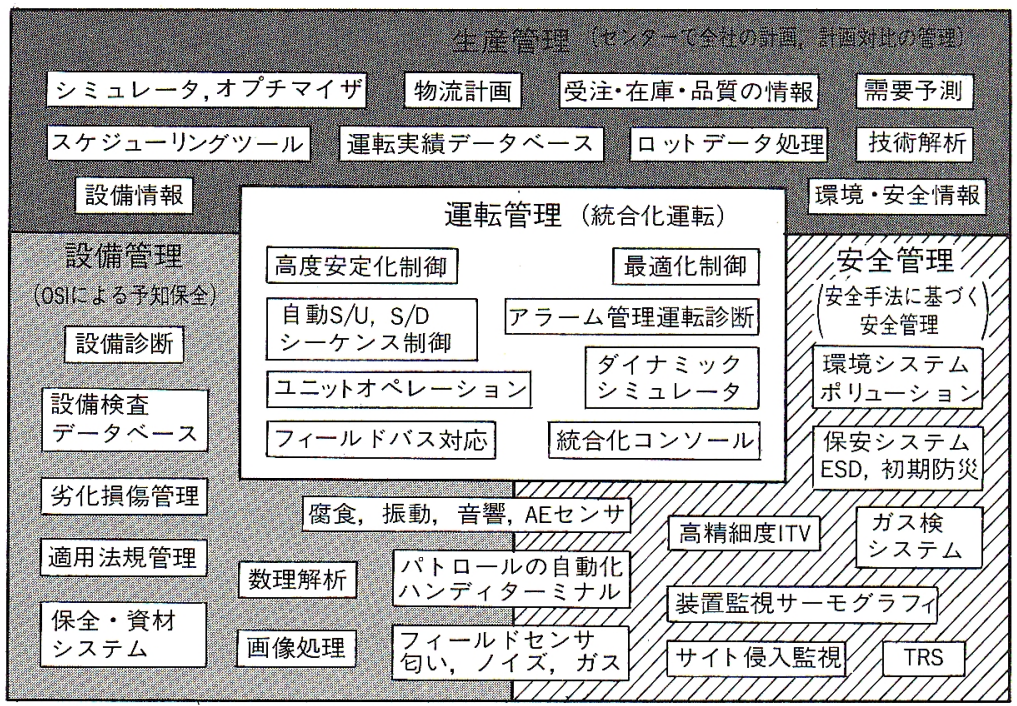

図 2 次世代生産システム（プロダクションセンタ）

従来, 紙パルプ工場の運転はパルププラント，抄紙 機, パワープラント，その他用排水等のユーティリ ティープラントの分野に分かれてそれぞれのプラント ごとに独立して運転されている。そして相互に関連す る情報は社内電話, 或いは会議等で伝達される。そこ でプロダクションセンタの基本概念としてこれらの分 散していな生産活動を統合化することにある。

パルププラント, パワープラント，ユーティリティ プラントそして生産計画等の生産活動に携わるオぺ レータ，スタッフ，保全メンバを一堂に配し，労働環 境を一新して情報の一元化，共有化を図り全員のべク トルを合わせることによって迅速な対応が可能となる。 このような体制をとることにより目的意識が一つに緾 まり，一人ひとりが従来の職種の枠を越えて多能工化, その業務の幅が拡大することによってモチベーション も高揚する。図 3 にプロダクションセンタの機能関連 を示す。また写真 2 にプロダクションセンタルームの イメージ写真を示す。

プロダクションセンタを実現させるには図 2 に示す 各機能の実現が必要であるが，現在のところすべてが 実現しているわけではない。しかしながら確実に一歩 一歩進展しているといえる。ここでは個別の機能につ いての解説は別の機会に譲ることにして，運転の自動 化, 統合化の最終目標である無人化 (超省人化) とこ れを支える設備保全のテーマに絞って考察してみたい。

\section{3 無人化について}

1）完全無人化は不可能に近い

工場運転の無人化に対する要望は非常に強い。かつ

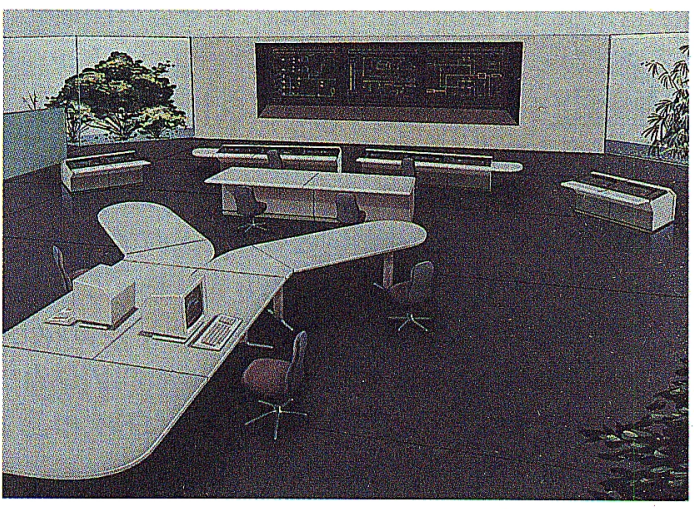

写真 2 プロダクションセンタのイメージ

て，省人化を考えたときは，それはコストの削減が主 な目的であった。しかし，今はむしろ人が集まらない という深刻な状況がある。そのために無人化の可能性 については多くの議諭がされてきた。しかし，最近で は完全な無人化は無理であるという意見が強い。むし ろ「超省人化」を目標にすると言うべきであろう。確 かに今までの多くの努力によって計器室で㗢く人の数 は大幅に減少した。

しかし，どうしても人手に頼らざるをえない部分が たくさん残っている。

第 1 に銘柄変更時, プラントのスタートアップ シャットダウン時, 負荷変動時などの非定常時の運転 は自動化が難しい。これらのときにはプラントを広い 範囲にわたり操作寸るので非線形性の影響などが出る。 また，種々の操業条件を考虑に入れて操作をしなけれ 


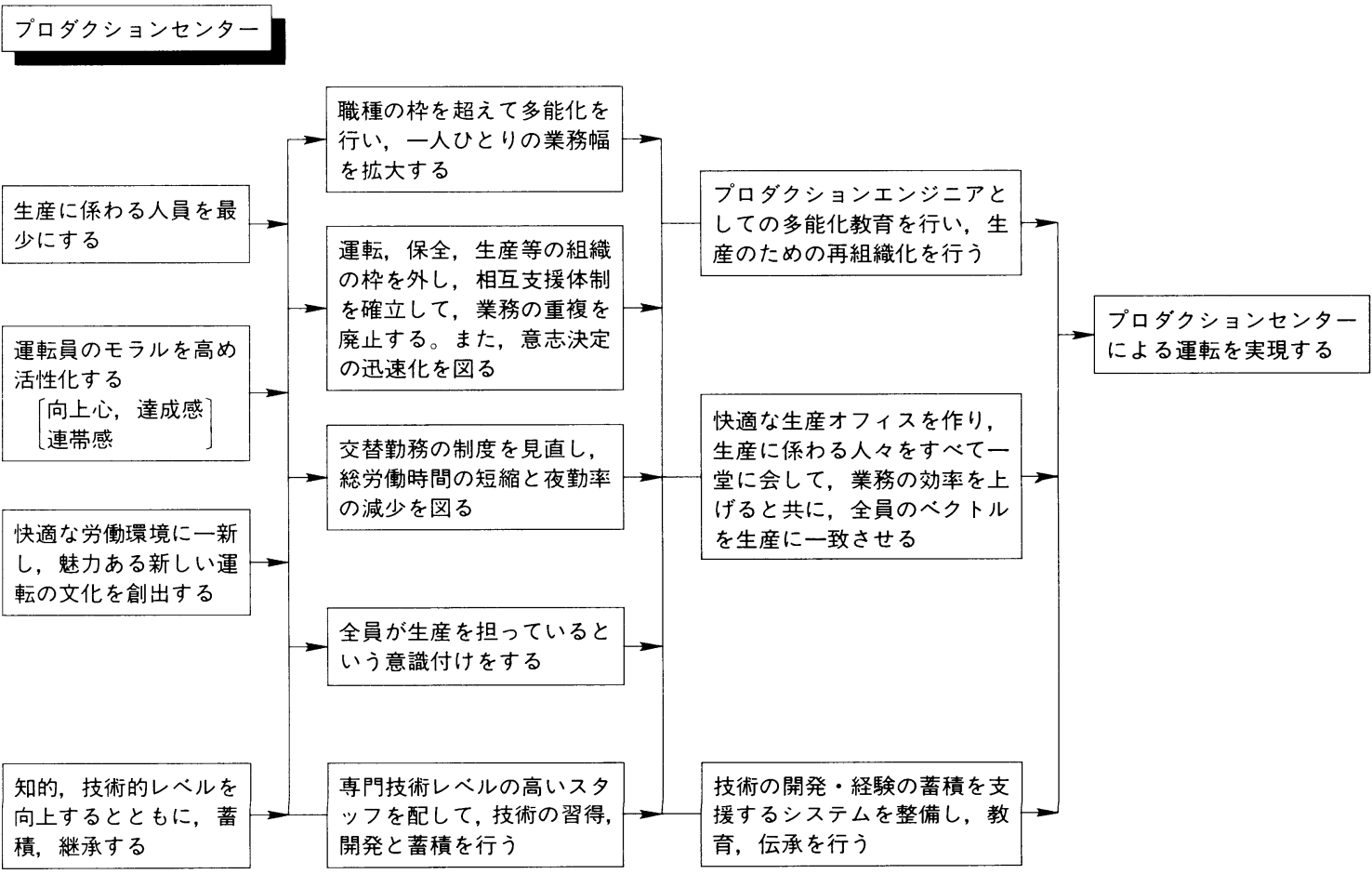

図 3 プロダクションセンタの機能

ばいけないので従来の方式ではなかなか生産しにくい。

第 2 に，例えばバーナ一, フィル夕の掃除などのよ うに運転のメンテナンスに関する作業は自動化が極め て困難である。

第 3 に場のパトロールによる液漏れ発見などの監 視作業も非常に白動化しにくい。液やガス漏れの発見 は人間の五感に頼っている部分が多く計測そのものが 容易でない。

第 4 に異常時，緊急時の処置である。例えば紙切れ 時の処置, 火災発生時の一次処置, 回転異常時の切替 え作業などである。

第 5 に特に既設プラントの場合，人手が必要である ことを前提に設計されているものがある。このような 場合は技術的にもコスト的にも計装技術による完全自 動化には限界がある。

このように，自動化を考えるとき，オンライン制御 と同等に，あるいはそれ以上に重要なのが機器の保全 や保安防災などであることが分かる。使用している回 転機やスクリーン，制御機器などの不具合や寿命等を 監視して丁度よいときに交換なり修理を行うことがで きれば人手は随分少なくてすむようになる。何か異常 が起こってから後にそれを修理, 復旧使用とすると事 前に行うより何倍もの時間と労力がかかるのである。
2）夜間の無人化

完全無人化は無理ではあるが，部分的無人化，例え ば夜間だけの無人化は可能である。夜間には銘柄変更 などの複雑な操作は行わず，なるべく静かに運転する。 最近, 運転のスケジューリングを簡単に行うソフト ウェアが開発されてきているので，このようなツール を使用して夜間や休日に運転状態の変更が来ないよう に計画を立てることが容易になってきた。また，後述 のニューラルネットワークなどを使用して，昼間のオ ペレータの操作をコンピュー夕に学習させておき, 夜 間はそのとおり運転させるということも出来るかも知 れない。

3）機械と人間の協調

われわれが目指すのは完全無人化ではない。より少 数の人員で運転しなければならないことは確かである が，工場から人間を全て排除することはできないし， またそれが好ましいとは限らない。むしろ必要なこと は人間にとって働きやすい環境作りである。コン ピュー夕の機能を充分に活用し，操業を容易にし，か つ操業の改善の助けとなるような運転支援システムを 構築することが重要である。オペレー夕室を快適で, かつ機能的にすることも重要である。このように人と 機械との調和の上に立って人が喜んで働けるようにす 
ること，その仕事を通じて人が生き甲斐を感ずるよう にすることが大切であり，技術の進歩はそのために活 用されるべきであると考える。

4）新しい技術の芽

以上述べてきたように自動化のためにはまだまだや らねばならないことが沢山ある。しかも難しいものが 多く，一朝，一夕には解決できない。しかし，そうい う中で，今いくつかの新しい技術が芽ばえかけている。 表 2 には計測制御の観点から見な代表的な新技術を举 げてある。

その一つに最近，話題になっているニューラルネッ トワークがある。これは人間の脳がもっている優れた 機能を模擬しようとするものであり, 特にその学習機 能が期待されている。ニューラルネットワークは人が あるパ夕ーンを繰り返し見て覚えるのと同様にして学 習することができる。例えば，人間は子どもの時から の学習の結果「2」という数字を見れば，それが少々 歪んでいても，大きく書かれていても小さく書かれて いても「2」であることが分かる。何故「2」と判定 したかということは説明しにくい。ともかく分かるの

表 2 無人化を支える新技術

\begin{tabular}{|c|c|c|c|}
\hline & 新 技 術 & 主要用途 & 応 用 例 \\
\hline $\begin{array}{l}\text { 操 } \\
\text { 業 } \\
\text { 理 }\end{array}$ & $\begin{array}{l}\text { スケジューリ } \\
\text { ング }\end{array}$ & $\begin{array}{l}\text { 製作順序, 装 } \\
\text { 置使用順序の } \\
\text { 決定 }\end{array}$ & $\begin{array}{l}\text { バッチプラントス } \\
\text { ケジューリング } \\
\text { 抄紙機 }\end{array}$ \\
\hline \multirow{4}{*}{$\begin{array}{l}\text { 運 } \\
\text { 転 } \\
\text { 管 } \\
\text { 管 }\end{array}$} & $\begin{array}{l}\text { 訓練シミュレ } \\
\text { ータ }\end{array}$ & 運転員の訓練 & $\begin{array}{l}\text { 蒸留塔, 都市がス } \\
\text { プラント }\end{array}$ \\
\hline & $\begin{array}{l}\text { プロセスシミ } \\
\text { ュレータ }\end{array}$ & $\begin{array}{l}\text { 運転支援, 異 } \\
\text { 常診断 }\end{array}$ & $\begin{array}{l}\text { 蒸留塔, 重合反応 } \\
\text { 器 }\end{array}$ \\
\hline & $\begin{array}{l}\text { エキスパート } \\
\text { システム }\end{array}$ & $\begin{array}{l}\text { 連転支援, 異 } \\
\text { 常誩断 }\end{array}$ & ボイラ運転支援 \\
\hline & 有向グラフ & 異常診断 & $\begin{array}{l}\text { 異常原因探索パッ } \\
\text { ケージ }\end{array}$ \\
\hline & $\begin{array}{l}\text { 統計解析ツー } \\
\text { ル }\end{array}$ & $\begin{array}{l}\text { プロセスモデ } \\
\text { ルの作成 }\end{array}$ & $\begin{array}{l}\mathrm{AR} モ テ ゙ ル \text { 作成ツ } \\
\text { 一ル }\end{array}$ \\
\hline 高 & ファジィ制御 & 操業の自動化 & $\begin{array}{l}\mathrm{BD} \text { プロフィル制御 } \\
\text { キルン制御 }\end{array}$ \\
\hline 度 & $\begin{array}{l}\text { ニューラルネ } \\
\text { ットワーク }\end{array}$ & $\begin{array}{l}\text { 学習機能を持 } \\
\text { つ制御 }\end{array}$ & $\begin{array}{l}\text { パタン認識を持つ } \\
\text { 運転支援システム }\end{array}$ \\
\hline 制 & 予測制御 & 制御性の改善 & 反応制御 \\
\hline 御 & $\begin{array}{l}\text { セルフチュー } \\
\text { ニング調節計 }\end{array}$ & $\begin{array}{l}\text { PID パラメー } \\
\text { タ自動チュー } \\
\text { ニング }\end{array}$ & $\begin{array}{l}\text { DCS の中で実現 } \\
\text { PID 制御系全般に } \\
\text { 適用 }\end{array}$ \\
\hline
\end{tabular}

である。これと间様なことをニューラルネットワーク はできる。「2」と判定するためのプログラムを作成し なくてもよいのである。

このような働きをするニューラルネットワークの学 習機能はパターン認識や唡像处理の分野で侍望である。 パルププラントやマシンでも連転状洗をパ夕ーンで判 断する場合は非常に多い。図 4 は滗者の夢であるが， 昼間に運転員が行った操作を兴浯させて挹き，夜間に それを模倣するシステムを作りたいと考えている。

ファジィ制御も各す媔で盛んに忍肬されている。紙 パルプ関連では， BDプロフィル制御やキルン制御な どに使用されている。こ㞦はプラントの制御操作にあ たり熟練したオペレータのやり方をコンピュータトで 実現させようとするものである。まずオペレータの操 作のやり方を音䌘によるルールで表現し，それをメン バーシップ関数などの助けを借りてコンピュータ上の アルゴリズムに㧍きかえる。従来のコンピュータアル ゴリズムと異なり吾唔で表現できるのが特徴であり， 表現のなかに「大きく動かす」などのようなあいまい な表現が許されることである。「ファジィ制御あるい は「あいまい制御」と呼ばれるのはこの理由による。 しかし，ルールとしてはあいまいな表現を含むことを 許されたのであるが, コンピュータのアルゴリズムに

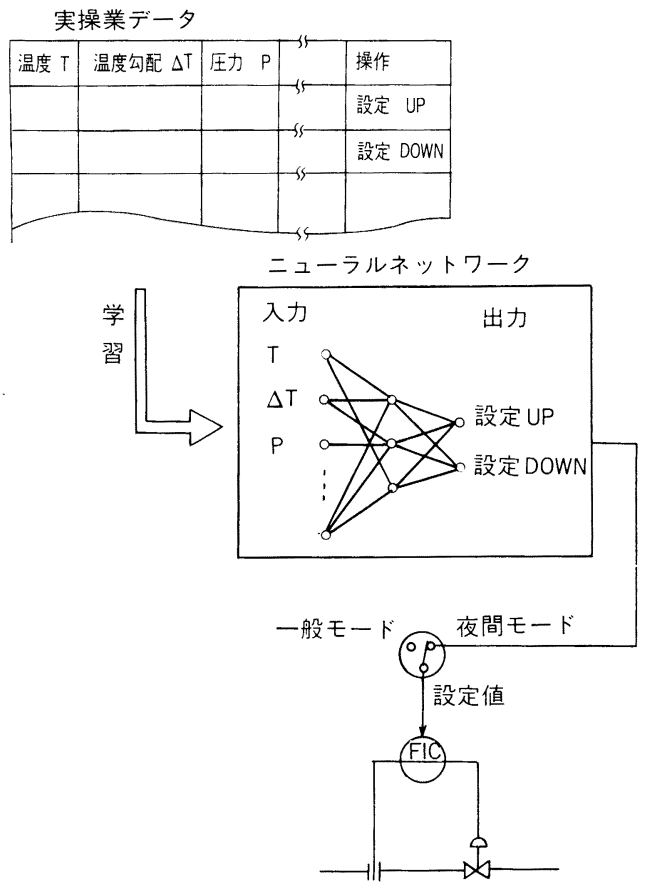

図 4 ニューラルネットワークによる夜間の自動 化 
置き換える際にはあいまいさを何らかの方法で定量化 しなければならない。従って，結果は決してあいまい ではない。

このファジィ制御はより一般的な表現を使えばルー ルベースト制御の一つであると言うことが出来る。こ のファジィ制御の閆題点はオペレー夕の操業を正しく ルール化しなければならないことと,メンバーシップ 関数を調整しなければならないことである。後者に関 してはトに述べたニューラルネットワークの学習機能 と組み合わせて自動的にやらせようという研究がされ ている。

益々強力になってくるコンピュータの力を背景に, シュミレータの技術も一層重要になるであろう。人間 は末来のことを事前に知りたいと望んでいる。天気予 報により午後雨が降ることが分かればカサを持って出 かけることが出来る。また，小さな前兆から大きな出 来事を予見できれば被害を最小限にくいとめることが 出来る。虹から大地震の発生が予測できれば対策の取 りようもある。

プラント運転の場合も同様のことが言える。プラン トのモデルを持ち，それに基づきシミュレーションを 行うことにより, 直接測定できない変数を推定したり, 異常時にその結果を推定したりすることが可能である。 そのよjなシミュレーターをオペレータのそばに置け ば，困ったときの相談役になるであろう。図 5 も筆者 の夢の一つであるが, シミュレー夕を使い直接測定で きないダイジェスタなどの内部状態を推定するのであ る。また希望の温度プロフィルを得る為にどのように 操作すればよいかシミュレータにより試行錯誤して求 めることができる。この場合, 正しいプラントのモデ ルが必要なので,これからはモデリングの技術がいつ

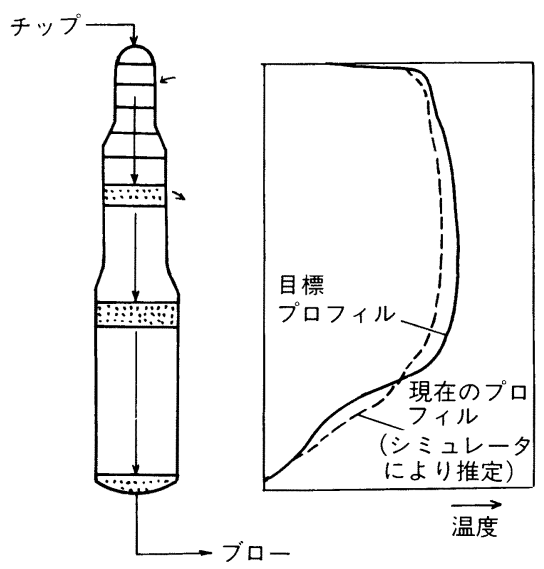

図 5 ダイジェスタの温度プロフィル監視
そう重要になる。

\section{4 設 備 保 全}

設備が高級化, 複雑化し, かつ大規模になって自動 化, 統合化が進んでくると, 設備の異常に対する対処 が非常に重要となってくる。自動化されればされるほ ど人間が手を出すことがなくなり，いざ異常になった 場合，緊張のあまりミスをしてしまうことは充分に考 えられることである。このようなことを回避するため の今後の設備保全はどうあるべきかを考えてみたい。

近年, TPM (Total Productive Maintenance) と いうことが注目されてきている。TPMは設備の総合 効率を最高に保つための活動である。TPMにおいて はメンテナンスエンジニアリングが重要な課題である。 メンテナンスエンジニアリングの歴史は比較的新しく, 当初の BM (Break Down Maintenance) つまり事後 保全から PM (Preventive Maintenance) 予防保全に 移行したのは 1960 年代である。PMはアメリカ技術の 輸入であったわけであるが 1970 年代に入り日本の自 動車産業で新しいメンテナンス方式が考え出された。 生産ラインが装置化して大掛かりになったので，その 一部が停止するとライン全体が停止してしまうことに なる。それを防ぐためには, オペレータもメンテナン スに参加する必要が生じ, 別のメンテナンス方式が考 えられ，これが TPM となったわけである。そこで TPM を実現するためにどんなメンテナンス方式が必 要であるかを考えてみる。

1) 夕イムベースからコンディンションベースのメ ンテナンスへ

従来のメンテナンスは, ある一定期間ごとに整備を 行う時間基準保全 TBM (Time Based Maintenance) が主であった。この TBM の問題点は, 設備ごとの劣 化のバラッキなどを考虑して短めの定周期で整備を行 うため必然的に保全の量も多くなる。つまり安全サイ ドでメンテナンスを実施するためにオーバメンテナン スの可能性がある。また時々経験することであるが, 運転および環境に馴染んでいた設備が整備により不調 になる，いわゆる初期不良の危険性もあり設備の信頼 性は期待するようなレベルにならない可能性がある。

そこで設備診断の結果により, 設置状況を加味した 上で必要な時期に必要な保全を実施する状態基準保全 CBM (Condition Based Maintenance) が必要になっ てくる。図6はある紙パルプ工場における実績デー夕 を基に事後保全 $\mathrm{BM}$, 時間基準保全 TBM, 状態基準保 全 $\mathrm{CBM}$ それぞれの保全量及びプラント停止の様子を 示したものである。棒グラフの横幅は保全のための期 間, 高さは保全量, 面積が保全の総量または保全コス 

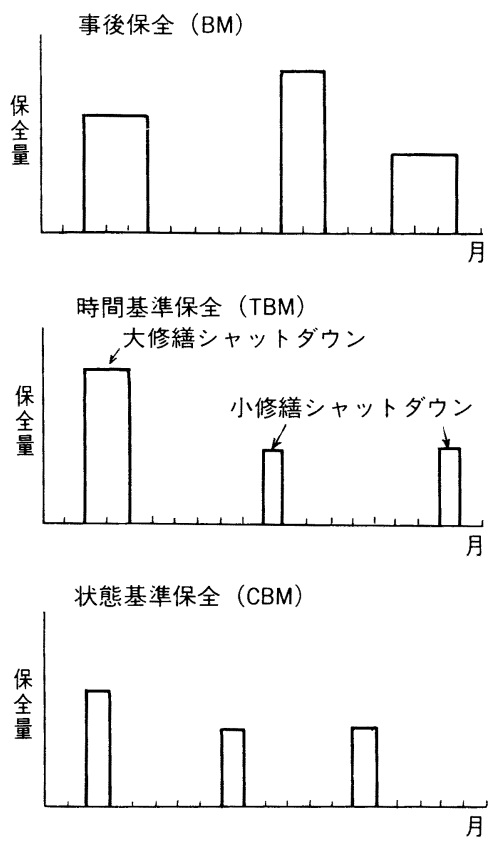

図 6 保全方式と保全量

トを表す。

CBM ではプラントの停止期間，保全コストいずれ も大幅に低下していることが分かる。単純比較ではあ るが, 保全量を比較すると $\mathrm{BM}: \mathrm{TBM}: \mathrm{CBM}=5$ ：

$2: 1$ となっている。

ではコンディションベースのメンテナンス CBM を 実現するためには何が必要かを考えてみる。

2） CBM 実現のための予知保全システム

CBM は設備のライフサイクルコストを低減し，プ ラント停止による機会損失を下げることにより設備 トータルのライフサイクルプロフィットを最大にする ことを目的としている。ではこの CBM の実現にはな にが必要かというと予知保全 PM (Predictive Maintenance）機能である。

予知保全とは状態監視によって予め故障を察知し事 前に対処することによって機会損失を最小限にするこ とである。具体的には設備診断により設備保全情報を 得る。設備診断には環境診断, 劣化診断, 寿命診断が あり, これらの診断情報をもとに設備の故障, 劣化の 状態, 更に劣化の原因であるストレスを正確に知るこ とができる。これらの情報から技術的根拠に基づいて 設備の状態の微分值（傾向）を求北, 将来の動向を予 知し必要な対策を施すことができる。

なお環境診断は既に数多くユーザで実施した経験も あり，紙パルプのユーザの例も多い。また計装設備の
劣化診断，寿命診断については機械設備に比べて診断 技術の歴史は浅く今後いろいろなI夫が必要である。

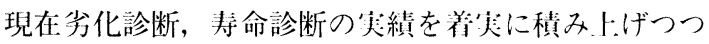
あり，近々これらの設備保全技術のシステム化が実現 し, 設備保全の新しい幕開けとなると確信する。図 7 に寿命診断の手順をホす。

3）保全面から見たフィールド機器技術

フィールド作業の軽減化のニーズが益々高まる中で フィールド機器へのニーズは二つの向向に向かってい る。一つはメンテナンスフリー化であり，もう一つは リモートメンテナンス化である。後者に対してはトラ ンスミッタ類のインテリジェント化への期待であり, またフィールドバスへの期待となっている。フィール ド機器の予知保全を実現するためにはりモートメンテ ナンス化への期待が大きい。既にインテリジェント化 され, リモートメンテナンス可能な機器も数多くある が, 殆どのものはパラメー夕变吏, 修止の川常運転管 理をメインとしたものである。しかしながら近年, 自 己診断機能を有しているものも開発されており, $\mathrm{O}_{2}$ 分 析計などは寿命予測まで含む自し診断機能を有してい る。今後はこれらのインテリジェント化されたフィー ルド機器 (含むバルブ, 操作端)をフィールドバスに より統合化し，一括してリモートメンテナンスするこ とが可能になってくる。フィールドバスは仕様の標準 化が遅れていたがようやく標準化の目途がたち 1 2 年以内には実現するであろう。したがって保全面から 見て機器の設備環境及び稼動状況に関する情報を収集 し，予知保全システムを確计することが急務になる。 一例を挙げると $\mathrm{B} / \mathrm{M}$ 計のリモートメンテナンス機能 は上記の設備環境および秎動状沉デー夕の収集が可能 となっている。

\section{4. おわりに}

今後の技術展望を行う.トで検討すべき課題は他にも たくさんある。特に生産管理システムについては重要 な課題ではあるがここではふれない。本件については 見識者の文献や意見が豊富に発表されているのでそち らに譲ることとする。ここでは連転管理, 設備管理に ついて筆者の拙い経験と知識をもとに願望を含めて述 べてみた。賢明なる読者諸见のご判断を仰ぎ，ご意見， ご指導を賜りたいと熱望する次第である。

なお，本稿作成に当たりいろいろご指導いただいた 横河電機㑣)元武，富田，沧理事に感謝の意を表します。 


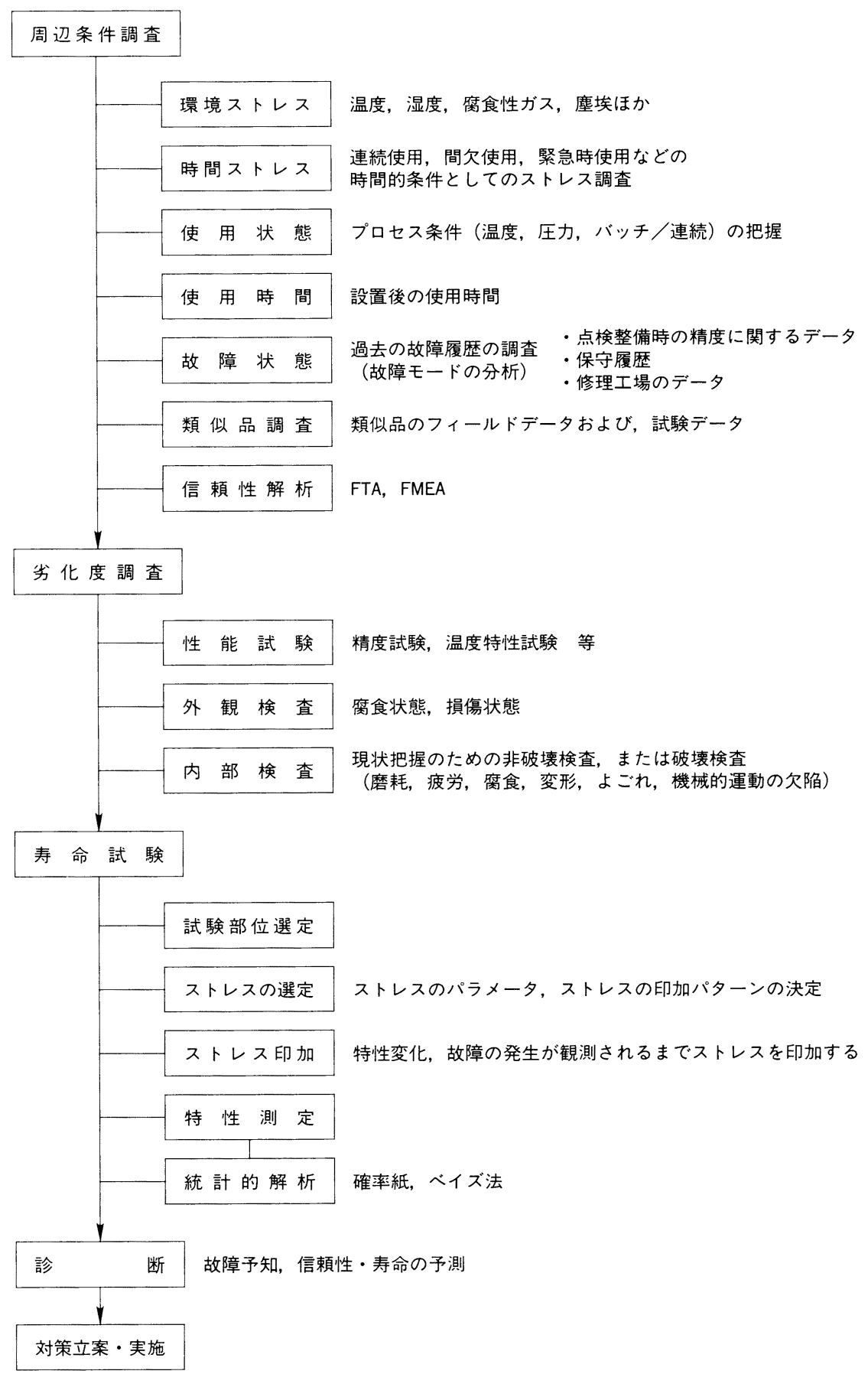

図 7 寿命診断手順（ハードウェア） 